\title{
SISTEM MANAJEMEN DATA MONOGRAFI DI KELURAHAN SIDODADI
}

\author{
Anton Yudhana1, Rusydi Umar' ${ }^{2}$, Faza Alameka ${ }^{3}$ \\ ${ }^{1}$ eyudhana@mti.uad.ac.id, ${ }^{2}$ rusydi@mti.uad.ac.id, ${ }^{3}$ faza.alameka@gmail.com \\ 1,2,3 Universitas Ahmad Dahlan
}

\begin{abstract}
Abstrak
Kelurahan merupakan salah satu lembaga yang mempunyai peranan penting dalam pemerintahan. Salah satu instansi pemerintahan yang dituntut dalam memperbaharui data monografi wilayahnya yaitu kelurahan Sidodadi yang berada pada kecamatan Samarinda ULU. Manfaat data monografi adalah mempermudah pihak yang ingin memerlukan informasi dan data dari suatu wilayah khususnya data monografi kelurahan Sidodadi. Dalam penelitian ini dijelaskan tentang perancangan dan pengembangan data monografi. Dalam pengembangan sistem ini penulis menggunakan pendekatan Model Incremental yang setiap tahapan-tahapan tersebut dilakukan secara berurutan. Setiap bagian yang sudah selesai dilakukan testing kemudian dikirim kepada pemakai untuk langsung dapat digunakan. Pembuatan sistem ini menggunakan Sistem Informasi terintegrasi server-side berbasis website yang memungkinkan pengembangan sistem yang dinamis dengan reusability. Data disimpan dalam bentuk database, sehingga mempunyai efisiensi dan integritas yang tinggi. Pengembangan dan perubahan sistem dapat dilakukan dengan mudah dan terpusat pada sisi server. Sedangkan program aplikasi tidak perlu diinstall dan didistribusikan kepada setiap client atau web browser.
\end{abstract}

Kata kunci: Kelurahan, Monografi, Database, Website.

ILKOM Jurnal IImiah work is licensed under a CCA-SA 4.0 International License.

\section{Pendahuluan}

Kecamatan Samarinda Ulu merupakan salah satu kecamatan yang terbentuk bersamaan dengan berdirinya Kota Samarinda. Kecamatan ini berada di ujung sebelah barat dari posisi geografis Kota Samarinda. Kecamatan Samarinda Ulu merupakan salah satu pusat Kota Samarinda karena banyaknya sarana dan prasarana yang tersedia di wilayah kecamatan ini.[1]

Pada tahun 2013, luas wilayah Kecamatan Samarinda Ulu seluas 22,12 km2. Wilayah terluas berada di Kelurahan Jawa yakni sebesar 34,72 persen dari luas wilayah Kecamatan Samarinda Ulu. Pada tahun 2013, kelurahan di wilayah Kecamatan Samarinda Ulu berjumlah kelurahan, antara lain Kelurahan Teluk Lerong Ilir, Kelurahan Jawa, Kelurahan Dadi Mulya, Kelurahan Sidodadi, Kelurahan Gunung Kelua, Kelurahan Air Putih, Kelurahan Air Hitam, dan Kelurahan Bukit Pinang. Berbeda dengan tahun 2010 yang masih berjumlah 9 kelurahan, tetapi sejak tahun 2011, Kelurahan Bugis bukan merupakan bagian dari Kecamatan Samarinda Ulu. [1]

Kelurahan merupakan salah satu lembaga yang mempunyai peranan penting dalam pemerintahan dan penyelenggaraan administrasi kemasyarakatan. Salah satu instansi pemerintahan yang dituntut terus memperbaharui data monografi wilayahnya adalah Kelurahan Sidodadi. Penyusunan data monografi kelurahan ini mengacu pada Peraturan Menteri Dalam Negeri Republik Indonesia Nomor 13 Tahun 2012 Tentang Monografi Desa dan Kelurahan. [2]

Dalam perancangan sistem manajemen data monografi ini, akan dirancang dengan Sistem Informasi terintegrasi server-side berbasis web yang memungkinkan pengembangan sistem yang dinamis dengan reusability. [3] Data disimpan dalam bentuk database, sehingga mempunyai efisiensi dan integritas yang tinggi. Pengembangan dan perubahan sistem dapat dilakukan dengan mudah dan terpusat pada sisi server. Sedang program aplikasi tidak perlu di install dan didistribusikan kepada setiap client atau web browser. [3]

Kelurahan Sidodadi sudah saatnya memanfaatkan teknologi informasi dan komunikasi yang dapat memudahkan semua pihak yang berkepentingan dengan data monografi di kelurahan Sidodadi tersebut.

\section{Landasan Teori}

\subsection{Kota Samarinda}

Kota Samarinda merupakan Ibu Kota Provinsi Kalimantan Timur, serta kota terbesar di Kalimantan Timur. Seluruh wilayah kota ini berbatasan langsung dengan Kabupaten Kutai 
Kartanegara, Kota Samarinda dapat dicapai dengan perjalanan darat, laut ataupun udara. Dengan sungai Mahakam membelah di tengah Kota Samarinda,[4] yang menjadi "Gerbang" menuju pedalaman Kalimantan Timur. Kota ini memiliki luas wilayah 718 kilometer persegi dan berpenduduk 805.688 jiwa pada tahun 2013 (Badan Pusat Statistik Kota Samarinda), menjadikan Kota ini berpenduduk terbesar di seluruh Kalimantan. [5]

\subsection{Kelurahan/Desa}

Kelurahan adalah wilayah kerja lurah sebagai perangkat daerah Kota Samarinda dibawah Kecamatan. [6] Desa adalah kesatuan masyarakat hukum yang memiliki batas-batas wilayah yang berwenang untuk mengatur dan mengurus kepentingan masyarakat sekitar/setempat, berdasarkan asal usul dan adat istiadat setempat yang diakui dan dihormati dalam sistem pemerintah negara kesatuan republik indonesia [2]

\subsection{Data Monografi}

Monografi kelurahan adalah himpunan data yang dilaksanakan oleh pemerintahan desa dan kelurahan yang tersusun secara sistematis, akurat dan terpadu dalam penyelenggaraan pemerintahan. [2] Kepala desa dan lurah bertanggung jawab atas monografi deas dan kelurahan yang di maksud adalah data umum, data personil, data kewenangan, data keuangan dan data kelembagaan. [2]

\section{Metode}

Pengembangan sistem manajemen monografi menggunakan model proses waterfall. Tahapannya dimulai dari tahapan perencanaan, analisis kebutuhan, perancangan, implementasi dan perawatan secara berurutan.

\subsection{Analisis Sistem Berjalan (Keadaan tempat penelitian)}

Bagian ini menggambarkan sistem yang sedang berjalan di lokasi penelitian yaitu kelurahan Sidodadi. Berdasarkan hasil wawancara dengan lurah dan pegawai administrasi keluraha Sidodadi maka terdapat prosedur yang terlibat dalam sistem yang berjalan diantaranya:

Sistem berjalan untuk data dinamis

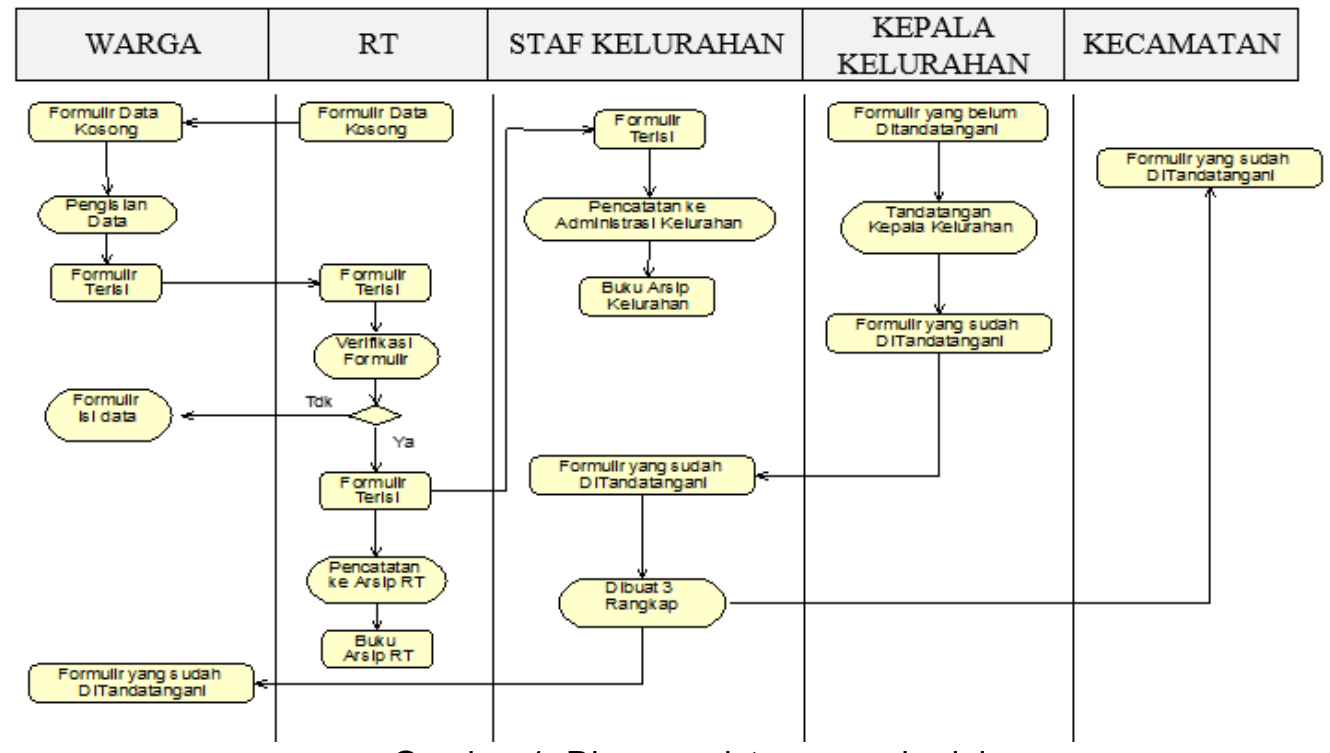

Gambar 1. Diagram sistem yang berjalan

\subsection{Analisis Kebutuhan Sistem}

1. Kebutuhan Fungsional

Kebutuhan yang berisis proses-proses apa saja yang dilakukan oleh sistem. Kebutuhan fungsional juga berisi informasi-informasi apa saja yang harus ada dan dihasilkan oleh sistem. Dalam sistem informasi ini kebutuhan fungsionalnnya diantara lain:

a. Dapat menyajikan data monografi kelurahan Sidodadi

b. Penyajian data monografi akan disimpan didalam sebuah database yang bersifat dinamis

c. Data monograf pembangunan yang dimaksud:

1. Data keagamaan

2. Data kesehatan 
3. Data pendidikan

4. Data sarana dan prasarana

2. Kebutuhan non fungsional

Kebutuhan yang terkait dengan spesifikasi perangkat yang dibutuhkan saat sistem diterapkan [8]

a. Kebutuhan perangkat lunak

Spesifikasi minimal perangkat lunak yang digunakan sistem adalah:

Tabel 1. Tabel kebutuhan perangkat lunak

\begin{tabular}{ll}
\hline \multicolumn{1}{c}{ Spesifikasi prangkat lunak } & \multicolumn{1}{c}{ Perangkat Lunak } \\
\hline Aplikasi Server & Xampp Server 1.6 \\
Bahasa Pemprograman & HTML, PHP, CSS, JavaScript dan lainnya \\
Desain Model Sistem UML & IBM Rasional Rose \\
\hline
\end{tabular}

b. Kebutuhan perangkat keras

Spesifikasi minimal perangkat keras yang digunakan adalah:

Tabel 2 Kebutuhan Perangkat keras

\begin{tabular}{ll}
\hline \multicolumn{1}{c}{ Perangkat keras } & \multicolumn{1}{c}{ Spesifikasi } \\
\hline Processor & Intel Pentium 4 \\
Memory & 1 gigabyte \\
Harddisk & $80 \mathrm{~GB}$ \\
\hline
\end{tabular}

3. Use-case Monografi

Usecase menggambarkan proses dari suatu organisasi yang dalam perancangan ini. Secara umum proses ini dapat dilihat sebagai berikut:

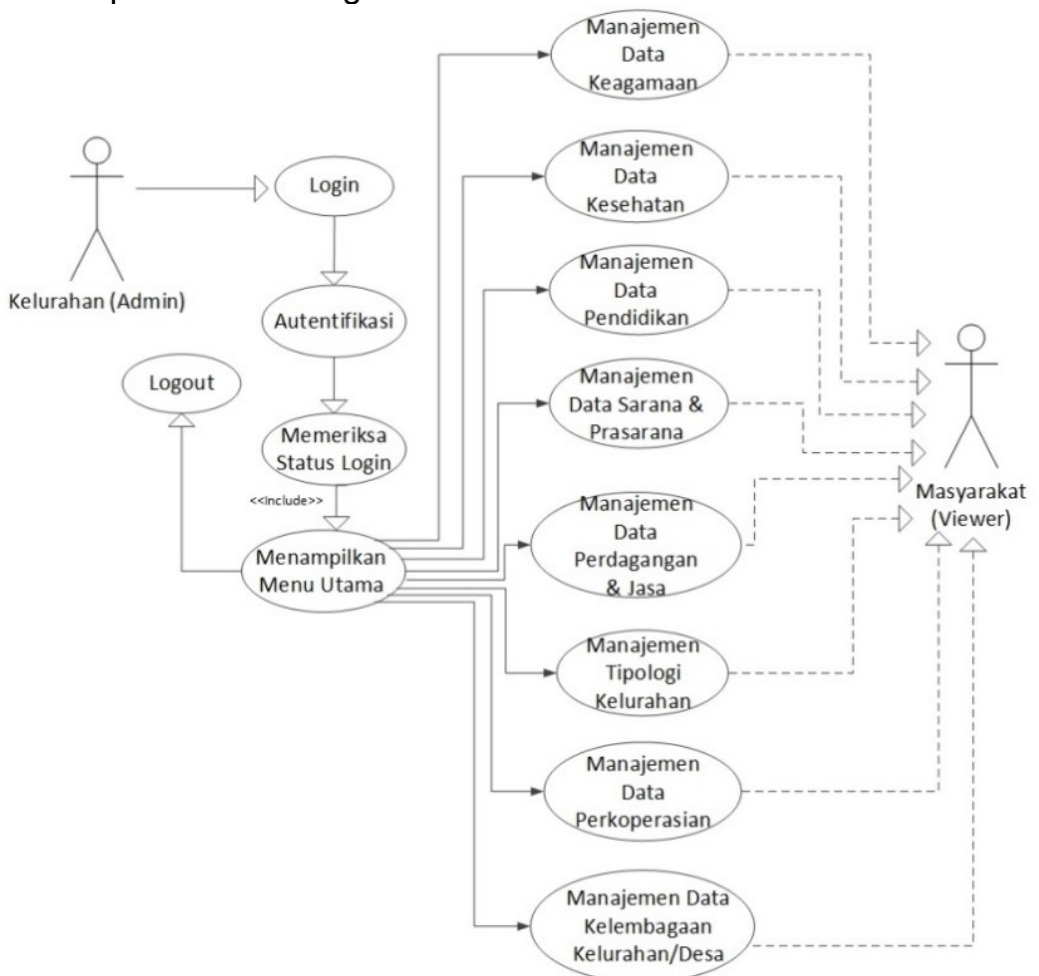

4. Activity Diagram

Gambar 2. Use-Case Monografi

Activity diagram Sistem monografi ini digunakan untuk mendokumentasikan alur kerja/ aktivitas-aktivitas pada sebuah sistem monografi Kelurahan Sidodadi, yang dimulai dari entitas admin hingga ke Viewer. Untuk lebih jelasnya dapat di lihat pada gambar berikut: 


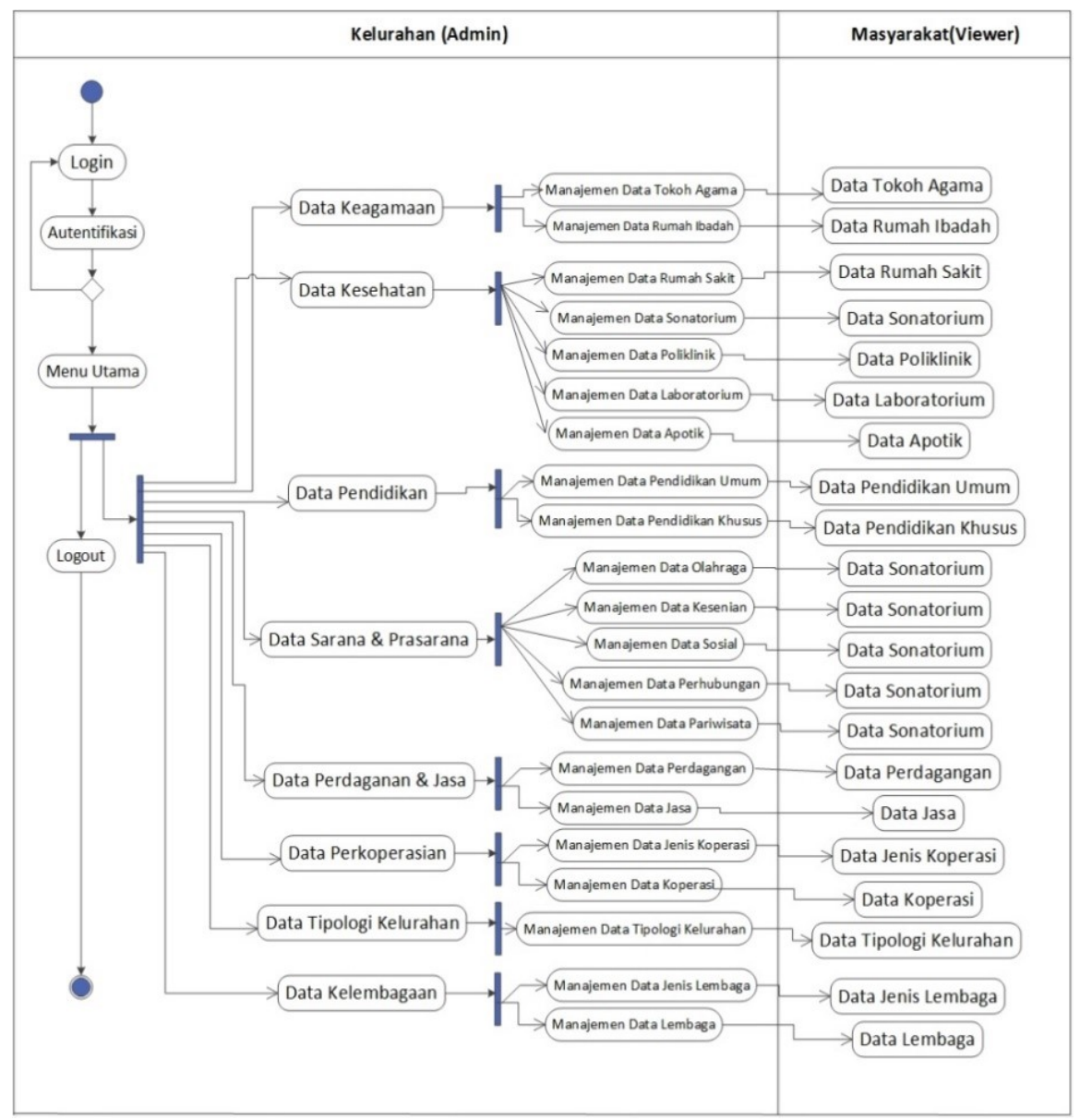

Gambar 3. Activity Diagram

\section{Class Diagram}

Class diagram adalah alat perancangan terbaik untuk pengembangan sistem. Diagram tersebut membantu pengembang mendapatkan struktur sistem sebelum kode ditulis dan membantu untuk memastikan bahwa desain sistem yang di rancang adalah desain terbaik.

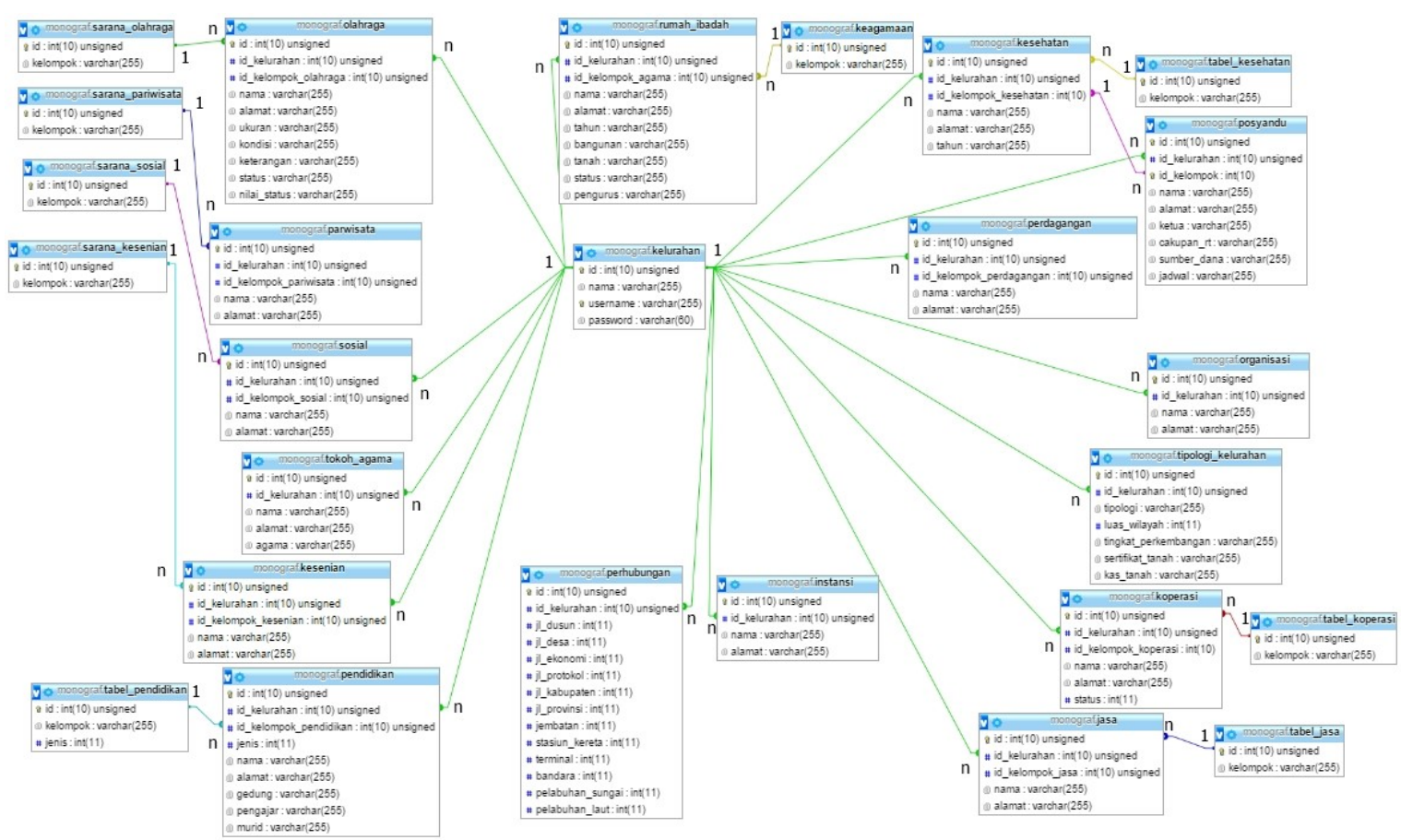

Gambar 4. Class Diagram monografi 


\section{Hasil}

Sistem manajemen monografi ini dapat di gunakan oleh pengguna yang terbagi atas 2 level yaitu: 1. Halaman Utama

Halaman utaman adalah halaman semua pengguna dapat mengakses sistem ini tanpa harus login. User dapat mengakses berbagai informasi dari sistem informasi manejemen data monografi

छMonografSamarind
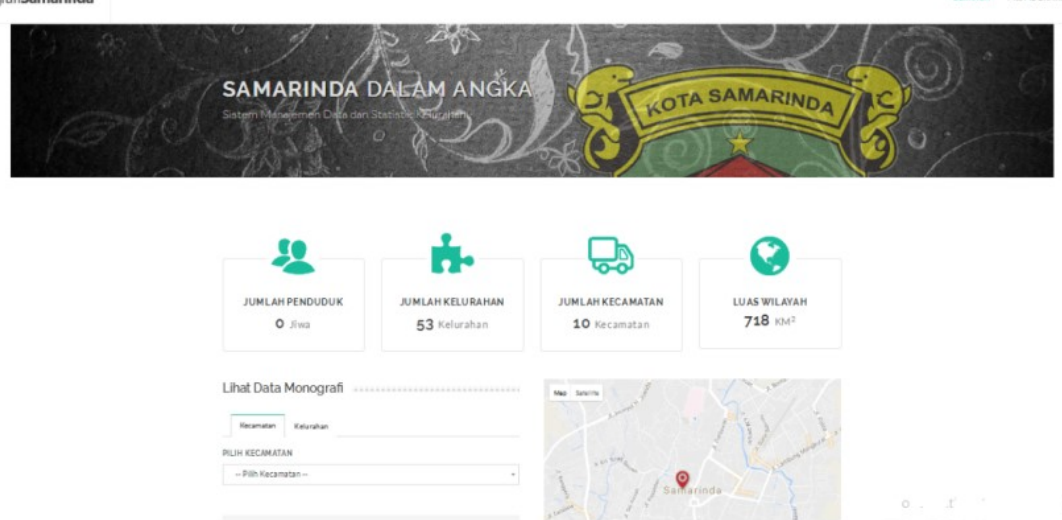

Gambar 5. Halaman utama

2. Halaman Data Agama

Halaman ini menampilkan grafik dari data agama yang ada di kelurahan sidodadi.

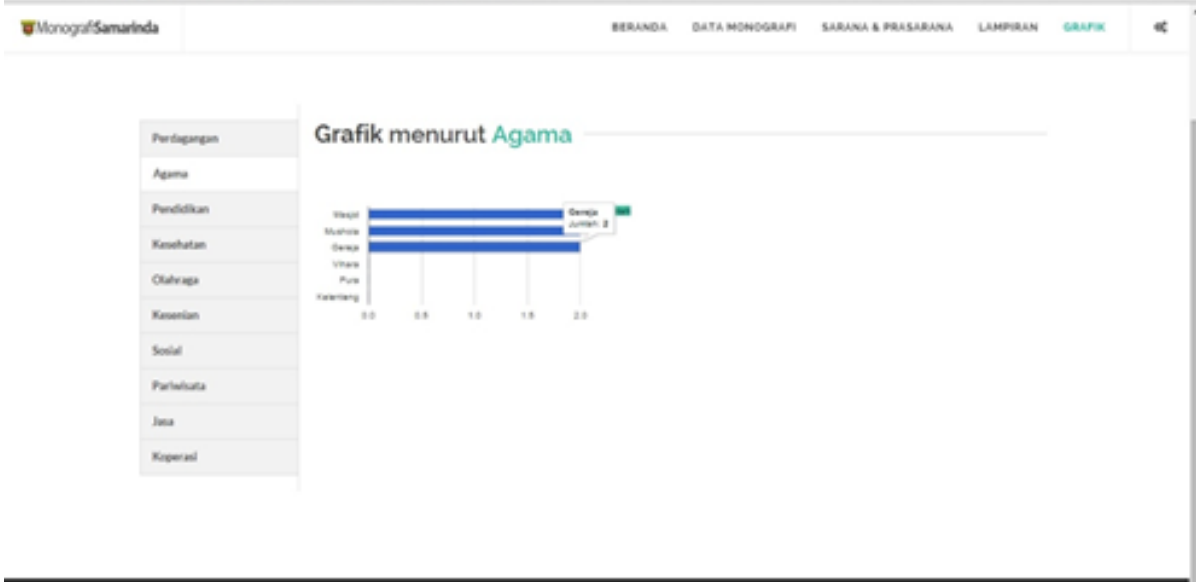

Gambar 6. Halaman data agama dalam grafik

3. Halaman Sarana dan Prasarana

Halaman ini merupakan menampilkan data sarana dan prasaran yang ada di kelurahan Sidodadi

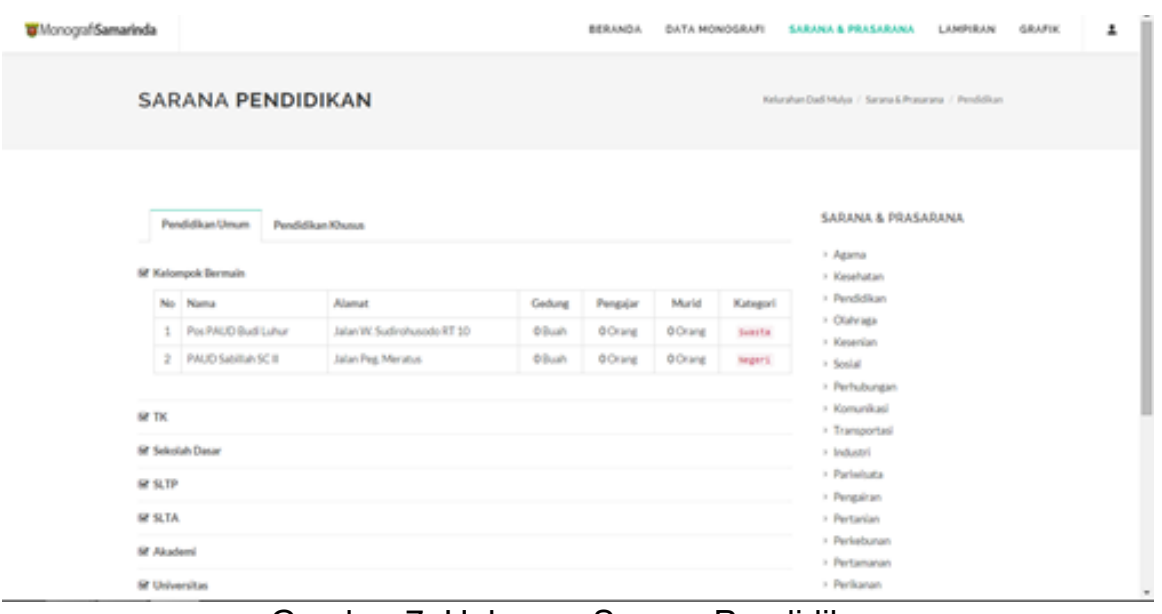

Gambar 7. Halaman Sarana Pendidikan 
4. Level Administrator

Level administrator dalam sistem manajeman data monografi ini adalah pengguna yang dapat mengelola data monografi yaitu pihak aparatur kelurahan yang telah dipilih. Untuk mengakses kedalam sistem, admin harus melalukan proses login.

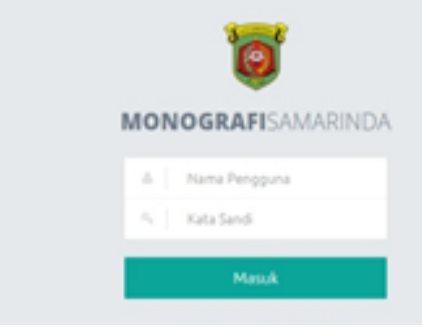

Gambar 8. Menu login

5. Menu Halaman Admin

Menu halaman admin adalah menu yang akan tampil pada saat admin telah memasukan username dan password ke dalam sistem yang benar

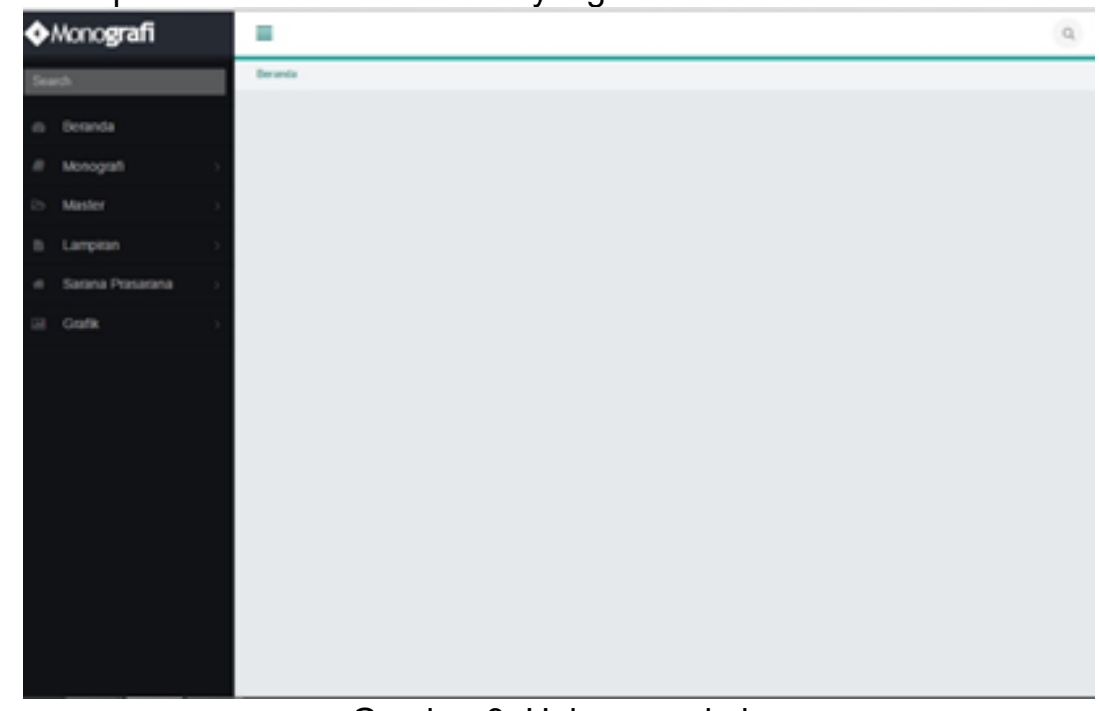

Gambar 9. Halaman admin

\section{Kesimpulan dan Saran}

\subsection{Simpulan}

Sistem manajemen data monografi yang menggunakan teknologi yang terkomputerisasi dalam sebuah database akan memberikan kontribusi kepada kelurahan maupun instansi yang terkait dalam manajeman data monografi dengan membangun sistem informasi yang disertai dengan DBMS (Database management system) sebagai pengarsipan serta pengelolaan data. Data disimpan dalam bentuk database, sehingga mempunyai efisiensi dan integritas yang tinggi. Pengembangan dan perubahan sistem dapat dilakukan dengan mudah dan terpusat pada sisi server. Sedangkan program aplikasi tidak perlu di install dan didistribusikan kepada setiap client atau web browser.

\subsection{Saran}

Penulis menyadarin dalam penelitian ini masih jauh dari kata sempurna untuk itu penulis ingin memberikan saran untuk perbaikan kedepannya

1. Dalam memudahkan pengoprasian sistem ini, petugas yang terlibat harus memiliki keterampilan dalam penguasaan komputer

2. Penulis berharap dalam penelitian ini dapat dikembangkan yang mengarah pada pembuatan aplikasi yang berbasis mobile.

3. Aplikasi ini dapat di implementasikan kepada instansi-instasi yang terkait sehingga memberikan kontribusi bagi masyarakat yang membutuhkan informasi tersebut. 


\section{Daftar Pustaka}

[1] PERDA Kota Samarinda No.2 Tahun 2010. (2010) Pembentukan Kecamatan Sambutan, Kecamatan Samarinda Kota Kecamatan Sungai Pinang, dan Kecamatan Loa Janan Ilir dalam wilayah Kota Samarinda. Samarinda. Pemerintah Kota Samarinda

[2] Peraturan Menteri Dalam Negeri Republik Indonesia Nomer 13 Tahun 2012. (2012). MONOGRAFI DESAN DAN KELURAHAN. Jakarta

[3] William Bongga. (2014). Pengembangan sistem manajemen data monografi dan statistik bidang pembangunan Samarinda. Skripsi

[4] Bappeda Kota Samarind, (2015) Rencana Pembangunan Jangka Panjang Daerah Kota Samarinda tahun 2005-2025. Samarinda. Bappeda Kota Samarinda.

[5] BPS Kota Samarinda. (2013) Samarinda dalam angka tahun 2013. Samarinda. Badan Pusat Satatistik 2013

[6] PERDA No1 Tahun 2006, (2006). Pembentukan Kelurahan dalam wilayah Kota Samarinda. Samarinda. Pemerintah Kota Samarinda.

[7] Narbuko, Cholid dan Abu Achmadi. 2012. Metodologi Penelitian. Jakarta : Bumi Aksara 